medRxiv preprint doi: https://doi.org/10.1101/2021.03.10.21253273; this version posted March 12, 2021. The copyright holder for this preprint (which was not certified by peer review) is the author/funder, who has granted medRxiv a license to display the preprint in perpetuity.

It is made available under a CC-BY-NC-ND 4.0 International license .

\title{
Kinetics and seroprevalence of SARS-CoV-2 antibodies - a comparison of 3 different assays
}

Elisabeth Kahre ${ }^{1}$, Lukas Galow ${ }^{1}$, Manja Unrath ${ }^{1}$, Luise Haag ${ }^{1}$, Judith Blankenburg ${ }^{1}$, Alexander

H. Dalpke ${ }^{2}$, Christian Lück ${ }^{2}$, Reinhard Berner ${ }^{1}$, Jakob P. Armann ${ }^{1}$

1 Department of Pediatrics, University Hospital and Medical Faculty Carl Gustav Carus, Technische Universität Dresden, Fetscherstrasse 74, 01307 Dresden, Germany

2 Institute for Medical Microbiology and Virology, Medical Faculty Carl Gustav Carus, Technische Universität Dresden, Fetscherstrasse 74, 01307 Dresden, Germany

Corresponding Author: Jakob Armann, University Children's Hospital, Fetscherstrasse 74, 01307 Dresden, Germany; email: jakob.armann@uniklinikum-dresden.de; telephone: +49 35145818568

\section{Abstract:}

\section{Purpose}

Comparing seroprevalence and antibody kinetics in three different commercially available assays for SARS-CoV-2.

\section{Methods}

Serostatus of COVID-19 patients was analyzed 5 months and 10 months after their infection, using three different assays: Diasorin LIAISON $^{\circledR}$, Euroimmun ${ }^{\circledR}$, Abbott Diagnostics ${ }^{\circledR}$ ARCHITECT.

\section{Results}

Seropositivity at baseline differed significantly depending on the assay (Diasorin 81\%, Euroimmun 83\%, Abbott 59\%). At follow-up antibody levels detected in the Diasorin assay were stable, while there was a significant loss in seropositivity in the Euroimmun and Abbott assays.

\section{Conclusion}

There are significant differences in SARS-CoV-2 antibody kinetics based on the specific assay used.

Trial registration number, date of registration: DRKS00022549, 29.07.2020 "retrospectively registered"

Keywords: seroprevalence, antibodies, SARS-CoV-2, assay, comparison 
medRxiv preprint doi: https://doi.org/10.1101/2021.03.10.21253273; this version posted March 12, 2021. The copyright holder for this preprint (which was not certified by peer review) is the author/funder, who has granted medRxiv a license to display the preprint in perpetuity.

It is made available under a CC-BY-NC-ND 4.0 International license .

\section{Declarations:}

Funding: This study was supported by a grant by the Federal State of Saxony.

Conflicts of interest/Competing interests: Alexander Dalpke, Reinhard Berner and Jakob Armann report grants from Federal State of Saxony during the conduct of the study.

Availability of data and material: We share data if reasonable requests are received. Requests should be directed to the corresponding author at jakob.armann@ uniklinikum-dresden.de

\section{Code availability: N/A}

Authors' contributions: Jakob Armann, Lukas Galow, Elisabeth Kahre, Reinhard Berner and Alexander Dalpke designed the study and wrote the protocol. Jakob Armann, Lukas Galow, Manja Unrath, Judith Blankenburg, Elisabeth Kahre and Luise Haag collected samples. Alexander Dalpke and Christian Lück performed serological testing. Jakob Armann, Lukas Galow, Elisabeth Kahre and Reinhard Berner analyzed and verified the data. Elisabeth Kahre, Lukas Galow and Jakob Armann wrote the manuscript. Alexander Dalpke, Christian Lück and Reinhard Berner reviewed the manuscript.

Text:

\section{Introduction}

Since the beginning of the SARS-CoV-2-pandemic [1] more than 112 Million cases and almost 2.5 Million [2] deaths have been reported worldwide. Serum antibody testing is becoming a critical tool, both in diagnosis of COVID-19 and in seroprevalence studies.

Most patients develop detectable antibodies within 14 days after their infection [3]. However, there is inconsistent evidence regarding the duration of antibody persistence with studies showing only short lived antibody responses [4] while others showing persistent serum levels [5].

While differences in patient characteristics and disease course might explain some contradictory findings, assay dependent differences might also play a role.

We analyzed SARS-CoV-2 seroprevalence and antibody kinetics over 9 months in 109 individuals using three different commercially available assays.

\section{Methods}

\section{Study Design}

Patients with PCR confirmed SARS-CoV-2 infection in Dresden (a city in Saxony/Germany with approximately 557.000 inhabitants) were invited via the local health department to participate in the AmbCoviDD19 study. 
medRxiv preprint doi: https://doi.org/10.1101/2021.03.10.21253273; this version posted March 12, 2021. The copyright holder for this preprint (which was not certified by peer review) is the author/funder, who has granted medRxiv a license to display the preprint in perpetuity.

It is made available under a CC-BY-NC-ND 4.0 International license .

After informed consent was obtained, $5 \mathrm{~mL}$ of peripheral venous blood was collected from each individual to assess SARS-CoV-2 IgG antibodies at baseline and 9-12 months after their infection (follow-up). Additional information about age, comorbidities, regular medication, COVID-19-symptoms, disease course and test indication were obtained.

The AmbCoviDD19 study was approved by the Ethics Committee of the Technische Universität (TU) Dresden (BO-EK-137042020) and has been assigned clinical trial number DRKS00022549.

\section{$\underline{\text { Laboratory Analysis }}$}

We assessed SARS-CoV-2 IgG antibodies in all samples using three commercially available assays.

First, chemiluminescence immunoassay (CLIA) technology for the quantitative determination of anti-S1 and anti-S2 specific IgG antibodies to SARS-CoV-2 was used: Diasorin LIAISON ${ }^{\circledR}$ SARS-CoV-2 S1/S2 IgG Assay. Antibody levels $>15.0 \mathrm{AU} / \mathrm{ml}$ were considered positive and levels between 12.0 and $15.0 \mathrm{AU} / \mathrm{ml}$ were considered equivocal.

Second, an ELISA detecting IgG against the S1 domain of the SARS-CoV-2 spike protein, Euroimmun ${ }^{\circledR}$ Anti-SARS-CoV-2 ELISA, was used; a ratio $<0.8$ was considered negative, $0.8-$ 1.1 equivocal, $>1.1$ positive.

Third, chemiluminescent microparticle immunoassay (CMIA) intended for the qualitative detection of IgG antibodies to the nucleocapsid protein of SARS-CoV-2, Abbott Diagnostics ${ }^{\circledR}$ ARCHITECT SARS-CoV-2 IgG, was used; an index (S/C) of $<1.4$ was considered negative, $>/=$ 1.4 was considered positive.

\section{Statistical Analysis}

Analyses were performed using IBM SPSS 25.0 and Microsoft Excel 2010. Statistical comparisons between groups were performed using the Fishers' exact test for categorical variables and T-test for means. Correlations were assessed using a Spearman's Rank correlation coefficient ( $r$ ). All tests were 2 -sided, and $p$ values? $<$ ? 0.05 were considered statistically significant.

\section{Funding}

This study was supported by a grant of the Federal State of Saxony, Germany.

\section{Results}

Overall, 109 individuals with a positive PCR in respiratory samples between March and May 2020 were enrolled in this study. 57/109 (52\%) were female, median age was 46 years, $2 / 109$ (1.8\%) were younger than 19 years, 8/109 (7.3\%) required hospitalization and 92/109 (84\%) reported COVID-19 related symptoms (see Table 1 for full patients' characteristics).

Median time between first serological testing and positive PCR was 144 days (4.8 months). 
medRxiv preprint doi: https://doi.org/10.1101/2021.03.10.21253273; this version posted March 12, 2021. The copyright holder for this preprint (which was not certified by peer review) is the author/funder, who has granted medRxiv a license to display the preprint in perpetuity. It is made available under a CC-BY-NC-ND 4.0 International license .

92/109 (84\%) participants had detectable antibodies against SARS-CoV-2 in at least one assay; 88/109 (81\%) were Diasorin positive while 90/109 (83\%) Euroimmun positive and 64/109 (59\%) Abbott positive.

$88 / 109$ (81\%) participants had detectable antibodies against SARS-CoV-2 in at least two different assays at baseline. Of these, $1 / 88(1 \%)$ had no detectable antibodies in the Diasorin, 25/88 (28\%) in the Abbott whereas all of these participants had at least equivocal results in the Euroimmun assay. 62/109 (57\%) individuals had detectable antibodies in all three assays at baseline (Table 2 a, Fig. 1).

Time between infection and serological testing (146 days vs. 141 days), age (44 vs. 46 years), female gender ( $51 \%$ vs. $57 \%$ ) hospitalization rate $(8 / 88(9 \%)$ vs. $0 / 21(0 \%))$ and frequency of reported symptoms $(75 / 88(85 \%)$ vs. $17 / 21(81 \%)$ ) did not differ significantly between seropositive and seronegative individuals (Table 3 ).

Seropositivity, however, differed significantly depending on test indication. While 44/50 (88\%) participants with a defined SARS-CoV-2 positive contact were seropositive, 18/19 (95\%) were positive with a travel history, only 16/27 (59\%) were seropositive when tested solely based on symptoms (Fig. 2).

Median time between second antibody assessment (follow-up) and infection was 295 days (9.8 months) (Table 1). 101/109 (93\%) participants had detectable antibodies in at least one assay. 89/92 (97\%) with detectable antibodies at baseline in at least one assay continued to have detectable antibodies in at least one assay at follow-up. 91/109 (83\%) were Diasorin positive, 85/109 (78\%) Euroimmun positive and 26/109 (24\%) Abbott positive (Table 2 a).

However, while $86 / 88$ (98\%) of participants with initially detectable antibodies in the Diasorin assay continued to have detectable antibodies in this assay, numbers were significantly lower for the Euroimmun (73/90 (81\%) $p$ 0.0004) and the Abbott (19/64 (30\%) $p$ 0.0001 ) (Table $2 \mathrm{~b}$ ). In addition mean antibody levels were stable in the Diasorin assays over time while they dropped significantly in the Euroimmun and Abbott assays (Fig. 3).

At follow-up, 77/109 (71\%) had detectable antibodies in at least two different assays (Table 2 a); 71/88 (81\%) individuals with two positive serological tests at baseline continued to have detectable antibodies in two assays; $15 / 17$ (88\%) individuals no longer tested positive in two different assays continued to have detectable antibodies in the Diasorin, while none of these continued to have detectable antibodies in the Euroimmun or Abbott. 24/109 (22\%) had detectable antibodies in all three assays at follow-up (Table 2 a, Fig. 1).

Five out of 21 (24\%) individuals without detectable antibodies in the Diasorin assay at baseline had detectable antibodies at follow-up, 7/19 (37\%) in the Euroimmun and 7/45 $(16 \%)$ in the Abbott respectively. Of the 17 individuals without detectable antibodies in any assay at baseline, $12(71 \%)$ had detectable antibodies in at least one assay at follow-up (3 Diasorin / 10 Euroimmun / 3 Abbott). Two individuals reported a positive SARS-CoV-2 PCR testing between baseline and follow-up. Both had initially no detectable antibodies in any assay, one had antibodies in all three assays at follow-up, one had detectable antibodies in the Diasorin and Euroimmun. Five individuals had no detectable antibodies in any assay at 
medRxiv preprint doi: https://doi.org/10.1101/2021.03.10.21253273; this version posted March 12, 2021. The copyright holder for this preprint (which was not certified by peer review) is the author/funder, who has granted medRxiv a license to display the preprint in perpetuity.

It is made available under a CC-BY-NC-ND 4.0 International license .

both times. Four out of five were tested by PCR based on symptoms alone, while $1 / 5$ was tested due to travel history.

\section{Discussion}

The overall seroconversion rate in our study is comparable to large population based seroprevalence studies [6, 7], however the differences in seroprevalence detected by different assays are striking. While at baseline the Diasorin and Euroimmun provide comparable results (Fig. 1), the seroprevalence in the Abbott is $20 \%$ lower compared to the other assays. At follow-up these differences become even more pronounced. While the Diasorin shows stable persistent antibody levels, seropositive rates detected with Euroimmun and Abbott decrease significantly over time, leading to a possible underestimation of seropositivity of up to $60 \%$. These differences might at least partly explain contradicting findings in longitudinal antibody kinetic studies.

Given the intra-individual differences, patient characteristics seem unlikely to explain the discrepancies between the different assays. Differences in antibody persistence based on targeted epitopes might play a role comparing Diasorin and Euroimmun with Abbott. However, the significant difference between Diasorin and Euroimmun at follow-up - both detecting antibodies targeting the spike protein of SARS-CoV-2 - requires further investigation.

In addition, antibodies to the nucleocapsid protein of SARS-CoV-2 are thought to be useful in differentiating between seroconversion after infection and vaccination. Given the substantial loss of these antibodies over time in our sample, this approach might be less feasible than expected.

It is remarkable that $71 \%$ of individuals without any detectable SARS-CoV-2 antibodies 4-5 months after their infection had measurable levels later at 9-10 months. One possible explanation could be that their initial short lived antibody response was boostered during the study period through repeat exposure. Further immunological studies - including T-cell assays - are needed to investigate this further. The observation that the only PCR confirmed repeat infections occurred in individuals without a detectable antibody response at baseline is somewhat reassuring and might point to a correlation between antibody response and immunity.

The lack of significant associations between seropositivity and patient characteristics in our study compared to previous [5,7] might be explained by the relatively long time period between infection and baseline serological testing as well as the rather homogenous study population with mild clinical courses.

The significant differences in seropositivity based on test indication is of particular interest though and most likely due to an increased rate of false positive PCRs in populations with a lower pre-test-probability. While this association is well described in the literature [8] these results are an important reminder that even highly specific test as the SARS-CoV-2 RT-qPCR do have a measurable false positive rate [9]. This observation needs to be given special 
medRxiv preprint doi: https://doi.org/10.1101/2021.03.10.21253273; this version posted March 12, 2021. The copyright holder for this preprint (which was not certified by peer review) is the author/funder, who has granted medRxiv a license to display the preprint in perpetuity.

It is made available under a CC-BY-NC-ND 4.0 International license .

consideration when implementing population-based screening programs in asymptomatic individuals.

\section{Conclusion}

There are significant differences in SARS-CoV-2 antibody kinetics based on the specific assay used. In our cohort the Diasorin LIAISON ${ }^{\circledR}$ assay performed best regarding long term detection of seropositivity. There is a significant difference in seropositivity in PCR-positive individuals based on the indication for PCR-testing.

\section{REFERENCES}

1 Zhu N, Zhang D, Wang W, et al. A Novel Coronavirus from Patients with Pneumonia in China, 2019. N Engl J Med 2020;382(8):727-33. doi:10.1056/NEJMoa2001017 [published Online First: 24 January 2020].

2 European Centre for Disease Prevention and Control. COVID-19 situation update worldwide, as of week 7, updated 25 February 2021 2021. Available at:

https://www.ecdc.europa.eu/en/geographical-distribution-2019-ncov-cases Accessed February 28, 2021.

3 Sun B, Feng $Y$, Mo X, et al. Kinetics of SARS-CoV-2 specific IgM and IgG responses in COVID-19 patients. Emerg Microbes Infect 2020;9(1):940-48.

4 Carsetti R, Zaffina S, Piano Mortari E, et al. Different Innate and Adaptive Immune Responses to SARS-CoV-2 Infection of Asymptomatic, Mild, and Severe Cases. Front Immunol 2020;11:610300. doi:10.3389/fimmu.2020.610300 [published Online First: 16 December 2020].

5 Zhang X, Lu S, Li H, et al. Viral and Antibody Kinetics of COVID-19 Patients with Different Disease Severities in Acute and Convalescent Phases: A 6-Month Follow-Up Study. Virol Sin 2020;35(6):820-29. doi:10.1007/s12250-020-00329-9 [published Online First: 22 December 2020].

6 Pollán M, Pérez-Gómez B, Pastor-Barriuso R, et al. Prevalence of SARS-CoV-2 in Spain (ENECOVID): a nationwide, population-based seroepidemiological study. The Lancet 2020;396(10250):535-44.

7 Gudbjartsson DF, Norddahl GL, Melsted P, et al. Humoral Immune Response to SARS-CoV-2 in Iceland. N Eng/ J Med 2020;383(18):1724-34. doi:10.1056/NEJMoa2026116 [published Online First: 1 September 2020].

8 Jackson BR. The dangers of false-positive and false-negative test results: false-positive results as a function of pretest probability. Clin Lab Med 2008;28(2):305-19, vii.

9 Surkova E, Nikolayevskyy V, Drobniewski F. False-positive COVID-19 results: hidden problems and costs. The Lancet Respiratory Medicine 2020;8(12):1167-68. 
Table 1 Patients' characteristics

\begin{tabular}{|l|l|l|}
\hline Age (years) & Mean (Range) & $46(4-80)$ \\
\hline Gender & Female & $57(52 \%)$ \\
\hline $\begin{array}{l}\text { Symptomatic SARS-CoV-2 } \\
\text { infection }\end{array}$ & & $92(84 \%)$ \\
\hline Hospitalization & & $8(7 \%)$ \\
\hline \multirow{2}{*}{$\begin{array}{l}\text { Time interval from PCR to } \\
\text { baseline (days/months) }\end{array}$} & Median & $144 / 4.8$ \\
\cline { 2 - 3 } $\begin{array}{l}\text { Time interval from PCR to } \\
\text { follow-up (days/months) }\end{array}$ & Median & $127-154 / 4.2-5.1$ \\
\cline { 2 - 3 } & IQR & $295 / 9.7$ \\
\hline
\end{tabular}

$I Q R$, interquartile range

Table 2 Seroprevalence at baseline and follow-up

a) Comparison of assays between baseline and follow-up

\begin{tabular}{|l|l|l|l|}
\hline & Baseline & Follow-up & $p$ value \\
\hline Diasorin LIAISON ${ }^{\circledast}$ & $88 / 109(81 \%)$ & $91 / 109(83 \%)$ & n.s. \\
\hline Euroimmun ${ }^{\oplus}$ ELISA $^{\text {Abbott Architect }}{ }^{\boxplus}$ & $90 / 109(83 \%)$ & $85 / 109(78 \%)$ & n.s. \\
\hline $\begin{array}{l}\text { Seropositive in one } \\
\text { assay }\end{array}$ & $92 / 109(59 \%)$ & $26 / 109(24 \%)$ & 0.0001 \\
\hline $\begin{array}{l}\text { Seropositive in two } \\
\text { assays }\end{array}$ & $88 / 109(81 \%)$ & $101 / 109(93 \%)$ & n.s. \\
\hline $\begin{array}{l}\text { Seropositive in three } \\
\text { assays }\end{array}$ & $62 / 109(57 \%)$ & $77 / 109(71 \%)$ & n.s. \\
\hline
\end{tabular}

n.s., not significant

b) Development of antibodies from baseline to follow-up

\begin{tabular}{|l|l|l|l|}
\hline & Baseline & Follow-up & $p$ value \\
\hline Diasorin & 88 & 86 & n.s. \\
\hline Euroimmun & 90 & 73 & 0.0004 \\
\hline Abbott & 64 & 19 & 0.0001 \\
\hline
\end{tabular}

Table 3 Factors not influencing seropositivity at baseline

\begin{tabular}{|l|l|l|l|l|l|l|}
\hline Factors & $\begin{array}{l}\geq 2 \text { tests } \\
\text { positive }\end{array}$ & $\begin{array}{l}\geq 1 \text { test } \\
\text { negative }\end{array}$ & $\begin{array}{l}p \\
\text { value }\end{array}$ & $\begin{array}{l}\geq 1 \text { test } \\
\text { positive }\end{array}$ & $\begin{array}{l}\text { No test } \\
\text { positive }\end{array}$ & $\begin{array}{l}p \\
\text { value }\end{array}$ \\
\hline Female gender & $45 / 88(51 \%)$ & $12 / 21(57 \%)$ & n.s. & $48 / 92(52 \%)$ & $9 / 17(53 \%)$ & n.s. \\
\hline Age & $44(32-58)$ & $46(34-60)$ & n.s. & $43(31-58)$ & $49(40-60)$ & n.s. \\
\hline $\begin{array}{l}\text { Time interval } \\
\text { from PCR to } \\
\text { baseline }\end{array}$ & $146(129-156)$ & $141(97-149)$ & n.s. & $147(129-156)$ & $138(91-148)$ & n.s. \\
\hline Symptomatic & $75 / 88(85 \%)$ & $17 / 21(81 \%)$ & n.s. & $77 / 92(84 \%)$ & $15 / 17(88 \%)$ & n.s. \\
\hline Hospitalization & $8 / 88(9 \%)$ & $0 / 21(0 \%)$ & n.s. & $8 / 92(9 \%)$ & $0 / 17(0 \%)$ & n.s. \\
\hline
\end{tabular}




\section{Fig. 1}

a) Baseline
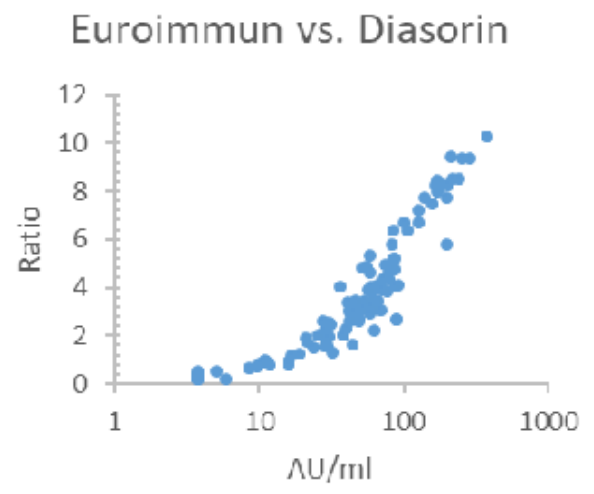

Abbott vs. Diasorin

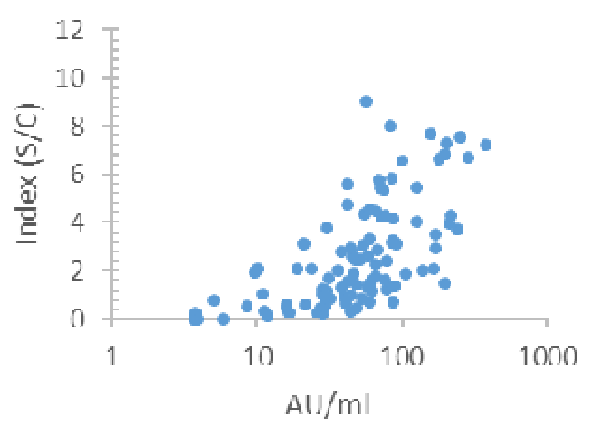

Abbott vs. Euroimmun

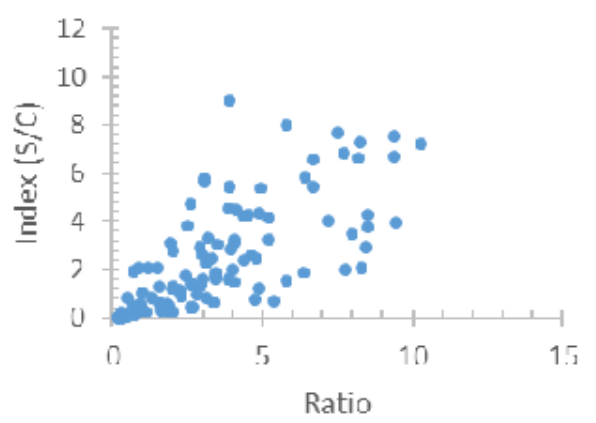

b) Follow-up

Euroimmun vs. Diasorin

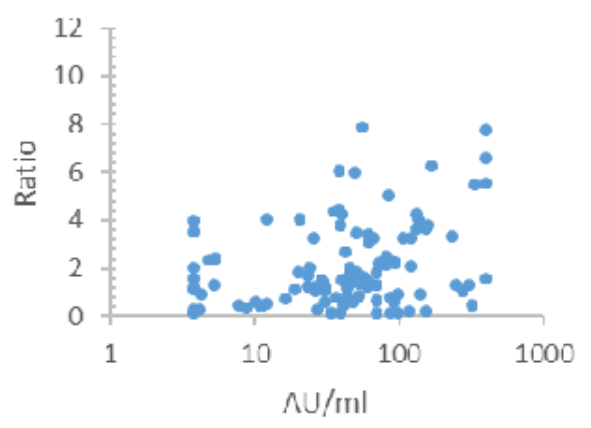

Abbott vs. Diasorin

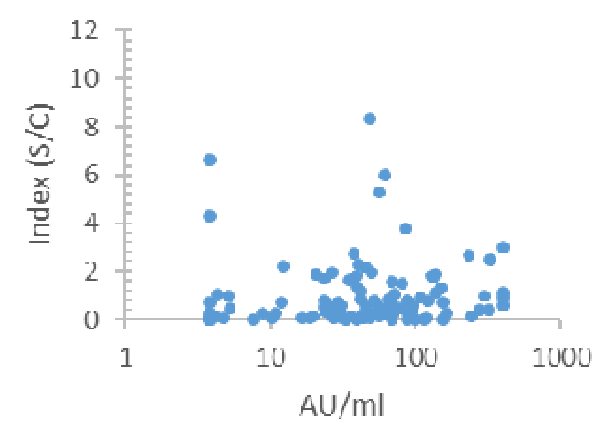

Abbott vs. Euroimmun

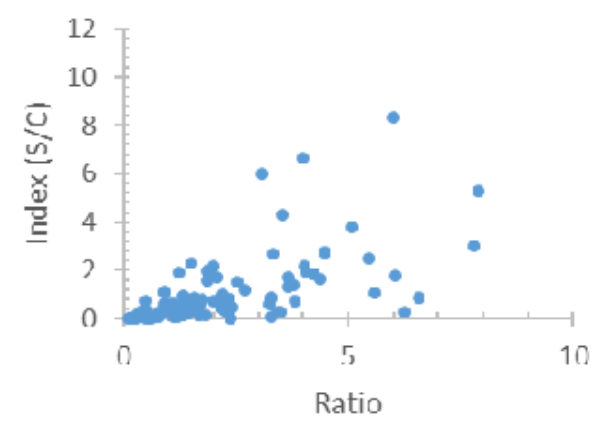

Relationship between levels of antibodies in different assays 
medRxiv preprint doi: https://doi.org/10.1101/2021.03.10.21253273; this version posted March 12, 2021. The copyright holder for this preprint (which was not certified by peer review) is the author/funder, who has granted medRxiv a license to display the preprint in perpetuity.

\section{It is made available under a CC-BY-NC-ND 4.0 International license .}

\section{Fig. 2}

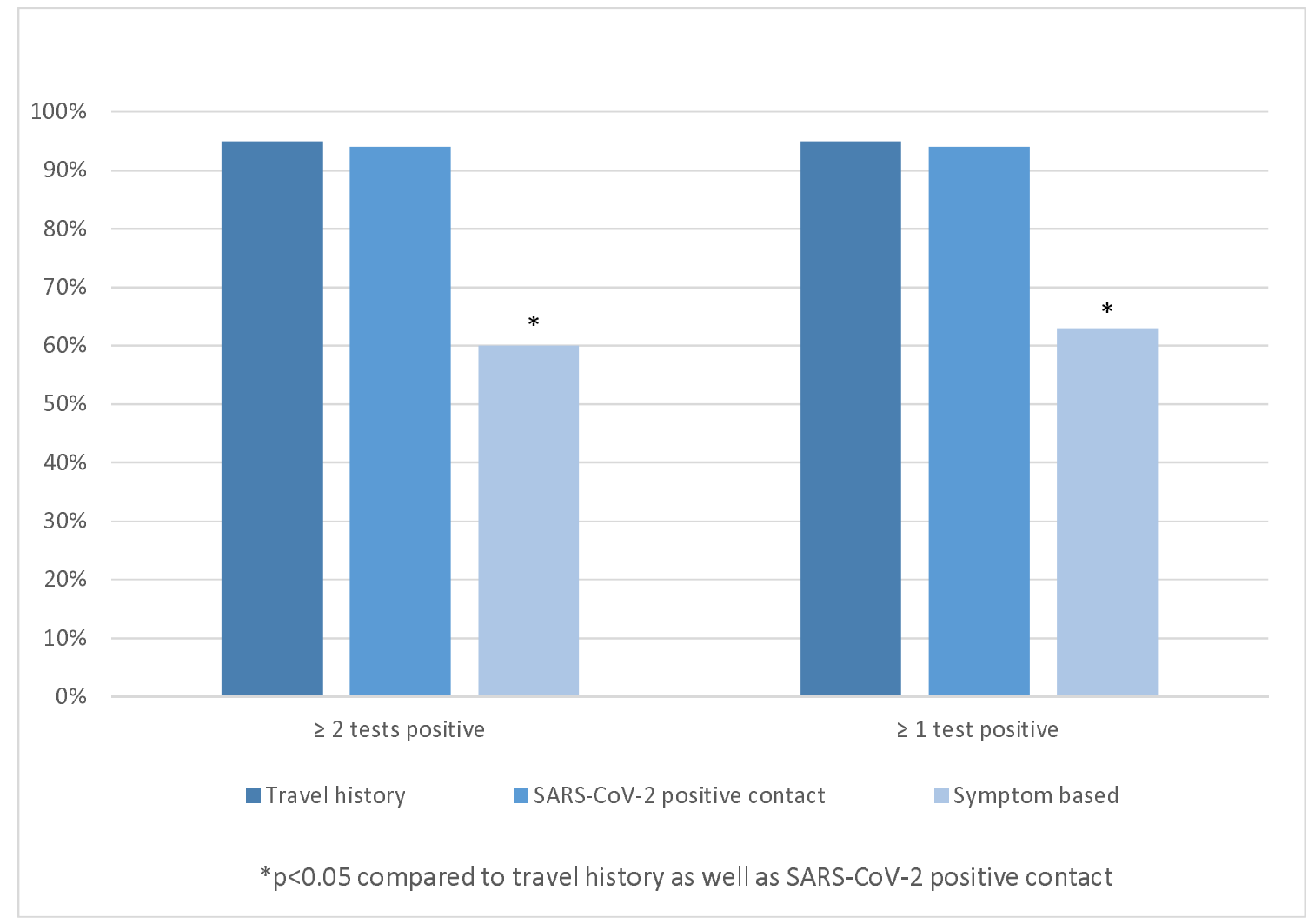

Factors influencing seropositivity; $p$ value refer to comparison between travel history and symptom based test indication as well as between SARS-CoV-2 positive contact and symptom based test indication 
medRxiv preprint doi: https://doi.org/10.1101/2021.03.10.21253273; this version posted March 12, 2021. The copyright holder for this preprint (which was not certified by peer review) is the author/funder, who has granted medRxiv a license to display the preprint in perpetuity.

\section{It is made available under a CC-BY-NC-ND 4.0 International license .}

Fig. 3
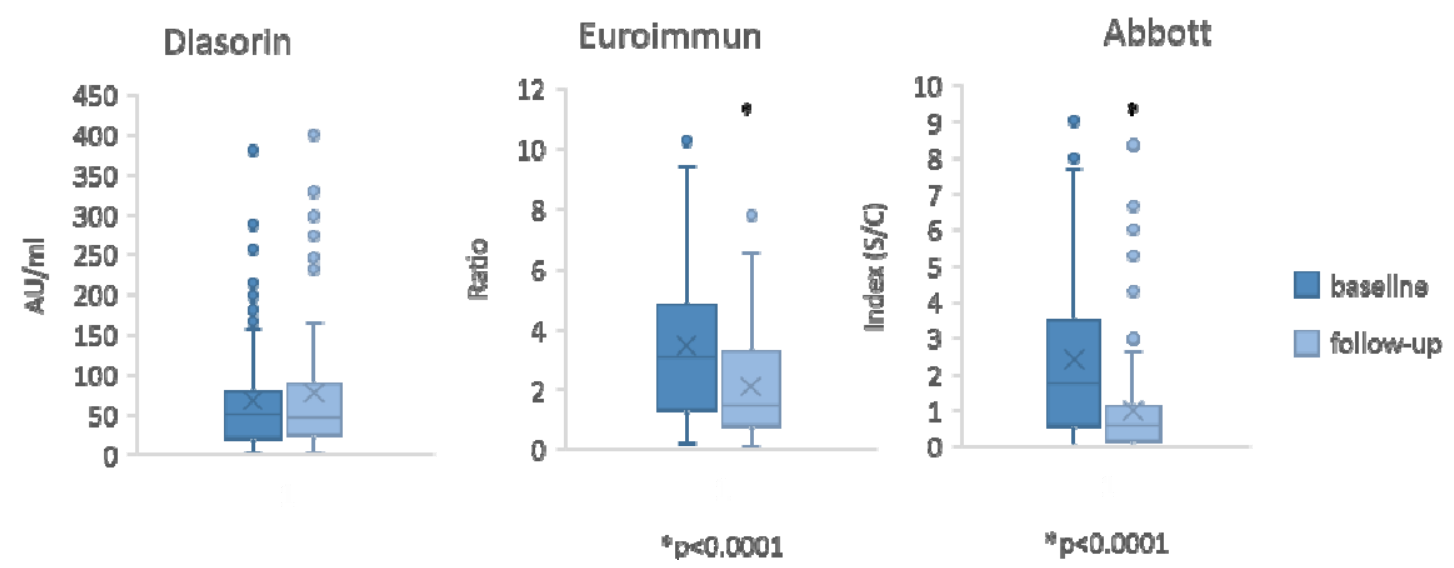

Mean antibody levels over time in different assays; $p$ value refer to comparison between baseline and follow-up 